\title{
Prevalence and Epidemics of Neoscytalidium Stem and Fruit Canker on Pitahaya (Hylocereus spp.) in South Florida
}

\author{
Cheng-Fang Hong, Romina Gazis, Jonathan H. Crane, and Shouan Zhang ${ }^{\dagger}$ \\ Tropical Research and Education Center, Institute of Food and Agricultural Sciences, University of Florida, Homestead, FL \\ 33031
}

\begin{abstract}
Since the 2000s, production of pitahaya (Hylocereus spp.) has increased significantly in South Florida. However, very limited information is available on the main diseases affecting this crop, particularly in regard to disease epidemiology and economic impact on the commodity. In this study, we surveyed five local pitahaya orchards and documented the most prevalent diseases and their causal agents. Three genera of fungal pathogens (Neoscytalidium, Alternaria, and Colletotrichum) were the major groups associated with symptoms on pitahaya cladodes (stems) during the early growing season. Among these, $N$. dimidiatum was identified as the most prevalent pathogen, with an overall isolation frequency of $29.8 \%$ (range, 13.9 to $47.2 \%$ ). Hence, the temporal progress of $N$. dimidiatum stem canker

canker incidence and the standardized area under the disease incidence or severity curve on cladodes, suggesting that high stem canker intensity in the early season may contribute to high fruit canker incidence and thereby impact the aesthetic and market value of fruits. In vitro assays showed that both conidial germination and mycelial growth of $N$. dimidiatum are positively correlated with increasing temperature, with a maximum growth area at $32^{\circ} \mathrm{C}$. This finding suggests a higher risk of infection, under an environment with high temperatures, which is common in South Florida. Data obtained in this study represent baseline knowledge for the future development of integrative management programs for controlling major diseases of pitahaya in South Florida.
\end{abstract} infection was monitored and the relationship between stem canker intensity (incidence and severity) and fruit canker incidence was investigated. A significant positive correlation was found between fruit
Keywords: disease development and spread, epidemiology, fruit, fungi, tropical plants, yield loss and economic impacts
Pitahaya or dragon fruit is a group of vine-like, fast-growing cacti, belonging to Hylocereus spp. that are native to the tropical forests of Mexico and Central and South America (Mizrahi et al. 1997; OrtízHernández and Carrillo-Salazar 2012). Pitahaya cladodes (stems) are succulent and triangular in cross-section with spines and areoles on the wavy ribs (Kishore 2016; Mizrahi et al. 1997). Under extended photoperiods, pitahaya plants switch from vegetative to reproductive growth, producing flower buds from the areoles on mature cladodes that further develop into red- or yellow-peel colored fruits with green to red bracts (Jiang et al. 2012; Mizrahi et al. 1997). The floral buds emerge in flushes and the number of flower waves may vary from two to more than eight per season (Jiang et al. 2012; Kishore 2016; Weiss et al. 1994). Once the floral bud is produced, it takes about 20 to 35 days for the flower to fully develop and approximately 30 additional days from pollination to harvest (Chang and Yen 1997; Kishore 2016). Depending on cultivar and location, harvest season may start as early as mid-May and last throughout November (Osuna-Enciso et al. 2016).

In the past 2 decades, global production of pitahaya has increased owing to the high net returns and short time period from planting to first harvest ( $\leq 2$ years), reported health benefits, soaring market demand, and relatively low crop maintenance (e.g., fewer disease and insect pest issues compared with other tropical crops) (Evans and

Current address of C.-F. Hong: Department of Plant Pathology, National Chung Hsing University, Taichung City, Taiwan, R.O.C. 40227.

${ }^{\dagger}$ Corresponding author: S. Zhang; szhang0007@ufl.edu

*The $\boldsymbol{e}$-Xtra logo stands for "electronic extra" and indicates that a supplementary figure and supplementary tables are published online.

The author(s) declare no conflict of interest.

Accepted for publication 11 December 2019.

(c) 2020 The American Phytopathological Society
Huntley 2011; Merten 2003; Ortíz-Hernández and Carrillo-Salazar 2012; Pagliaccia et al. 2015; Raveh et al. 1993). In addition, growers in South Florida consider pitahaya as a potential alternative fruit crop to avocado and citrus, two crops largely compromised by the major diseases laurel wilt and huanglongbing, respectively (Crane 2018).

Commercial production of pitahaya in the continental United States can be tracked back to the 2000s (Merten 2003; Steele and Crane 2006). Since then, pitahaya acreage has been steadily increasing in South Florida, with a recent estimate of $>720$ acres (Crane 2018). One viral and four fungal pathogens causing disease in South Florida and Southern California have been reported (Fernandez de Soto et al. 2014; Gazis et al. 2018; Palmateer et al. 2007; Patel and Zhang 2017; Sanahuja et al. 2016; Tarnowski et al. 2010). Three of the four fungal pathogens (Neoscytalidium dimidiatum, Bipolaris cactivora, and Colletotrichum gloeosporioides) have also been reported in other pitahaya growing areas, causing severe damage on cladodes and/or fruits (Fullerton et al. 2018; Taba et al. 2007; Takahashi et al. 2008; Wang and Lin 2005). Along with the increasing pitahaya acreage in South Florida, more and more pitahaya growers are faced with disease and pest issues (Fernandez de Soto et al. 2014; Gazis et al. 2018; Palmateer et al. 2007; Patel and Zhang 2017; Sanahuja et al. 2016; Tarnowski et al. 2010). However, information on the prevailing diseases and their biology, epidemiology, and impact on fruit quality and yield has not been well documented in this region thus far.

Limited information on the biology of the major pathogens affecting pitahaya has constrained the possibility to optimize management strategies related to the different growth stages of the crop. Currently, only limited fungicides, such as azoxystrobin (Fungicide Resistance Action Committee [FRAC] group 11) and cyprodinil plus fludioxonil (FRAC groups 9 and 12), are registered for managing pitahaya diseases in South Florida (Crop Data Management Systems 2019). Limited chemical tools promote reuse of the same chemistries, therefore increasing the risk of fungicide resistance development in pathogen populations. In addition, pitahaya fruit production can last up to 7 months. The necessity to rotate FRAC groups to reduce fungicide resistance and the limits on the amount 
and number of applications allowed per year make it imperative for a precise timing for the fungicide application based on the pathogen's biology.

To optimize management strategies and justify fungicide inputs, science-based knowledge of the major diseases affecting pitahaya is critical. The objectives of this study were (i) to investigate and document the major diseases of pitahaya in the early season of production, (ii) to monitor the temporal dynamics of the most important disease and its potential impact on fruit, and (iii) to investigate the effect of temperature on conidial germination and growth of the major pathogens affecting pitahaya in South Florida. The ultimate goal was to shed light on the epidemics of the major diseases affecting pitahaya under South Florida environmental conditions and to create a foundation for an evidence-based management plan to address the major diseases of this crop in the region.

\section{Materials and Methods}

Diseases associated with pitahaya during vegetative growth. Pitahaya cladodes with chlorotic to brown spots or lesions were collected biweekly from three to five commercial orchards (HL, PY, MW, JY, and MT) and one experimental orchard (Tropical Research and Education Center [TREC]) located in Homestead, Florida, from 19 March 2019 (week 12) to 12 June 2019 (week 24). The average ambient temperature during this period was $25.0^{\circ} \mathrm{C}$, the average minimum temperature was $20.2^{\circ} \mathrm{C}$, and the average maximum temperature was $29.8^{\circ} \mathrm{C}$. The average dew point was $20.7^{\circ} \mathrm{C}$ and relative humidity was $78.3 \%$ with a total of $185.9 \mathrm{~mm}$ of rainfall. In each orchard, three to five cladodes showing single spots or lesions were collected and transported to the laboratory for further investigation. Symptomatic cladodes were surface disinfected with $70 \%$ $\mathrm{EtOH}$ for 20 to $30 \mathrm{~s}$ and blot dried with a paper towel. Isolation from symptomatic tissues was based on 6 to 12 tissue samples plated on $2 \%$ water agar and incubated in the dark at $25^{\circ} \mathrm{C}$ for 3 to 7 days. The number of microorganisms isolated from the diseased tissues was recorded and the isolates were purified by transferring the hyphal tips onto potato dextrose agar (PDA) (Difco; BD Biosciences).

Since only fungi were recovered from symptomatic tissues, the isolates were further purified on PDA and incubated in the dark at $25^{\circ} \mathrm{C}$ for 7 to 14 days. For the pathogenicity tests, a 14-day-old mycelia plug ( $7 \mathrm{~mm}$ in diameter) colonized by each of the four isolates representing each fungal genus was placed on the surface of cladodes wounded with a sterile syringe needle (about $1 \mathrm{~mm}$ in depth). PDA plugs were used as negative controls. All agar plugs were removed 3 days after inoculation and the cladodes were further incubated in moist chambers at $25^{\circ} \mathrm{C}$ in the dark for 14 days. The lesion area that developed in each treatment was assessed using Fiji version 2.0.0 (Schindelin et al. 2012; Schneider et al. 2012).

Molecular identification of the predominant pathogen. Based on isolation frequency, Neoscytalidium sp. was identified as the predominant fungal pathogen affecting pitahaya cladodes during the early production season. Hence, four single-spore isolates (HL321N1, MW403N1, PY320N2, and UFE8N1) collected from three commercial orchards and TREC were grown on PDA for 7 days before DNA extraction. DNA was extracted using the DNeasy Plant Mini Kit (Qiagen) following the manufacturer's protocol. The internal transcribed spacer (ITS) region (White et al. 1990), partial $\beta$-tubulin gene (Glass and Donaldson 1995), and partial translation elongation factor $1-\alpha(E F 1-\alpha)$ gene (Carbone and Kohn 1999) were amplified (Supplementary Table S1). Each reaction consisted of $2.5 \mu$ of $10 \times$ PCR buffer, $0.5 \mu l$ of dNTP $(10 \mathrm{mM}), 0.25 \mu \mathrm{l}$ of Taq DNA polymerase $(5 \mathrm{U} / \mu \mathrm{l})(\mathrm{GenScript}$ USA Inc.), $0.25 \mu \mathrm{l}$ of each forward and reverse primer $(10 \mu \mathrm{M}), 2 \mu \mathrm{l}$ of template DNA, and distilled deionized $\mathrm{H}_{2} \mathrm{O}$ to a final volume of $25 \mu$. Thermocycler conditions for ITS, $\beta$-tubulin, and $\mathrm{EF} 1-\alpha$ were as follows: initial denaturing at $95^{\circ} \mathrm{C}$ for $3 \mathrm{~min}$, followed by 40 cycles of $30 \mathrm{~s}$ at $95^{\circ} \mathrm{C}, 45 \mathrm{~s}$ at $58^{\circ} \mathrm{C}$, and $2 \mathrm{~min}$ at $72^{\circ} \mathrm{C}$, with a final extension at $72^{\circ} \mathrm{C}$ for 8 min (Carbone and Kohn 1999; Glass and Donaldson 1995; White et al. 1990). PCR products were sequenced using the ABI 3730XL sequencers at the Molecular Cloning Laboratories. Sequences were edited and assembled using
Geneious 11 (Kearse et al. 2012) and used in BLAST searches against the NCBI GenBank database (https://blast.ncbi.nlm.nih. gov/Blast.cgi).

Temporal dynamics of stem canker and its relationship with fruit canker incidence. The temporal progress of Neoscytalidium stem canker was monitored between 19 March 2019 (week 12) and 29 May 2019 (week 22) at four commercial orchards (HL, PY, MW, and JY) and TREC. Thirty-four cladodes of H. undatus $\times H$. polyrhizus 'Natural Mystic' at TREC and 15 cladodes of $H$. undatus 'Vietnamese' at each of the commercial orchards were randomly tagged. All cladodes were symptomless at the beginning of the field survey. The length of the cladodes, the number of areoles, and disease intensity including disease incidence (number of diseased cladodes in total surveyed cladodes) and disease severity (proportion of diseased area on each cladode) were assessed biweekly until tagged cladodes stopped elongating.

To investigate the relationship between stem canker intensity and fruit canker incidence, the fruit canker incidence (number of diseased fruits in total surveyed fruits) was estimated twice during fruit development. The phenological stage of the fruits was assessed according to a Biologische Bundesanstalt, Bundessortenamt und Chemische Industrie (BBCH) scale (Kishore 2016). The first estimation was made in mid-June (week 24) when the third to the fourth wave of fruits were maturing (BBCH 817 to 819) or developing (BBCH 711 to 717 ). The second estimation was conducted in late July (week 30) when the sixth to seventh wave of fruits were maturing (BBCH 813 to 819 ) or developing (BBCH 711 to 717 ) (Kishore 2016). Because fruit phenology, productivity, and harvest dates varied among orchards, incidence data were pooled to a final sample size of between 90 to 120 fruits per orchard. The overall fruit canker incidence of each orchard was then plotted against the standardized area under the disease incidence curve (sAUDIC) and standardized area under the disease severity curve (sAUDSC) on cladodes.

Effect of cumulative temperature on conidial germination of $\boldsymbol{N}$. dimidiatum. Four $N$. dimidiatum isolates (HL321N1, MW403N1, PY320N2, and UFE8N1) were grown on PDA and incubated at $25^{\circ} \mathrm{C}$ in the dark for 14 days. Conidia were spread on $2 \%$ water agar and then incubated at $15 \pm 1,23 \pm 1,27,32$, and $37^{\circ} \mathrm{C}$. More than 180 conidia at each temperature were assessed for their germination 6,12 , and $24 \mathrm{~h}$ after incubation. The experiment was conducted twice and the germination proportion of each $N$. dimidiatum isolate was pooled and regressed against the cumulative temperature.

Effect of temperature on mycelial growth of $N$. dimidiatum. To evaluate the effect of temperature on mycelial growth, a mycelial plug ( $7 \mathrm{~mm}$ in diameter) of each aforementioned isolate was placed on PDA, and four plates were used for each treatment (isolate/ temperature). Plates were then incubated at $15 \pm 1,23 \pm 1,27 \pm$ 1,32 , and $37^{\circ} \mathrm{C}$, respectively, in the dark for 2 days. Colonies in each treatment were photographed at 24-h intervals and the area was measured using Fiji (Schindelin et al. 2012; Schneider et al. 2012). The mycelial growth rate was calculated using the following formula: $g r=\left(C_{48}-C_{24}\right) / 24$, where $g r$ is the mycelial growth rate and $C_{48}$ and $C_{24}$ are the colony area size 48 and $24 \mathrm{~h}$ after incubation, respectively. This experiment was conducted three times.

Data analysis. To test whether the isolation frequency of the three fungal pathogens recovered from the single spots or lesions $(n=252)$ was significantly different during the early production season, the overall isolation frequency was subjected to analysis of variance (ANOVA) followed by Tukey's honest significance difference (HSD) test for pairwise comparison among the three fungal isolates using the 'aov' and 'TukeyHSD' functions in the R environment ( $\mathrm{R}$ Core Team 2018).

To investigate whether the relative lesion sizes ( $r l s$, where $r l s$ is the lesion size caused by the fungus divided by the lesion size of negative control) were significantly different among fungal genera, the relative lesion size of each fungal pathogen was subjected to ANOVA and Tukey's HSD test in R environment. 
The sAUDIC and sAUDSC values for stem canker in each orchard were estimated using trapezoid integration (Shaner and Finney 1977) and then divided by the number of weeks surveyed. The relationship between early-season stem canker intensity and fruit canker incidence was determined by pooling fruit incidence data, by orchard, and plotting it against the sAUDIC and sAUDSC, respectively. To estimate the significance level of the linear regression, Pearson's correlation coefficient and $P$ values were calculated using the 'cor.test' function in $\mathrm{R}$ environment.

To evaluate the effect of cumulative temperature $\left({ }^{\circ} \mathrm{C}-\mathrm{h}\right)$ on conidial germination, the proportion of germinated conidia of each isolate was plotted against cumulative temperature. The following logarithmic model was fitted to the data to estimate the slope $(a)$ and intercept (b) for each isolate:

$$
\mathrm{y}=\mathrm{a}^{*} \ln (\mathrm{x})+\mathrm{b}
$$

where $y$ is the proportion of germinated conidia and $x$ is the cumulative temperature. Furthermore, $50 \%$ of germination was chosen as a cutoff threshold to predict the temperature at which $50 \%$ of conidia may germinate within $24 \mathrm{~h}$.

To test the effect of isolate, temperature, and isolate $\times$ temperature on mycelial growth rate $(g r)$, the $g r$ values were subjected to ANOVA followed by Tukey's HSD test. The R codes for all aforementioned analyses are available upon request.

\section{Results}

Temporal dynamics and identification of fungal isolates associated with diseases on pitahaya cladodes. Based on morphology, 115 fungal isolates belonging to four genera (Neoscytalidium,

Table 1. Relative lesion size caused by different fungal pathogens on the cladodes of Hylocereus undatus 'Vietnamese' at $25^{\circ} \mathrm{C}$ after 14 days of inoculation

\begin{tabular}{lc}
\hline Fungus & Relative lesion size $^{\mathrm{y}}$ \\
\hline Alternaria & $0.07 \pm 0.03 \mathrm{~b}^{\mathrm{z}}$ \\
Colletotrichum & $0.26 \pm 0.18 \mathrm{~b}$ \\
Neoscytalidium dimidiatum & $3.51 \pm 1.59 \mathrm{a}$ \\
\hline
\end{tabular}

$\mathrm{y}$ The lesion area for each treatment was assessed using Fiji (Schindelin et al. 2012; Schneider et al. 2012). Relative lesion size is the lesion area caused by the fungus divided by the lesion area of negative control.

$\mathrm{z}$ Values are presented as the means \pm standard error of the mean of relative lesion size caused by different fungal pathogens ( $n=4$ isolates/fungus). Means followed by the same letter are not significantly different based on Tukey's honest significance difference at $P=0.05$.

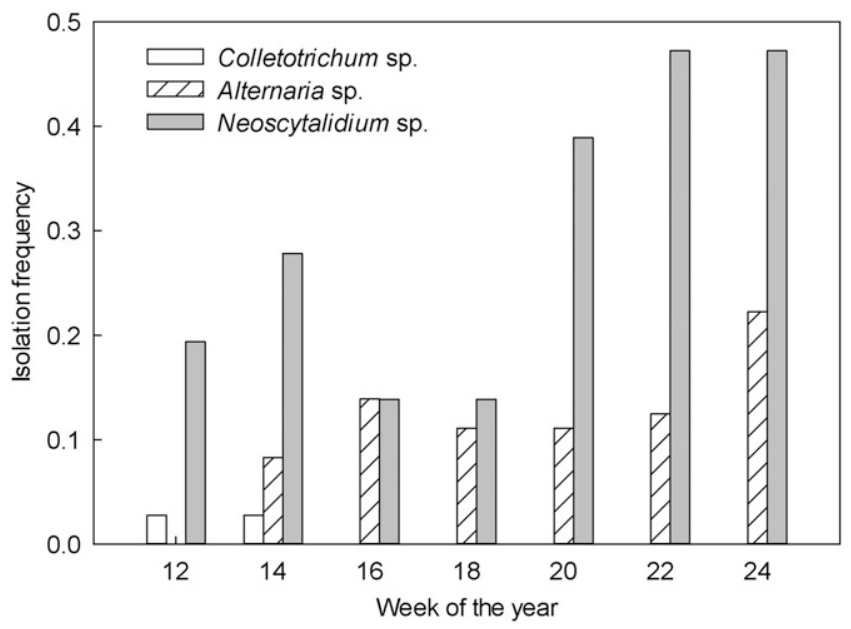

Fig. 1. Isolation frequency of three fungal pathogens affecting pitahaya cladodes between 19 March and 12 June 2019 in South Florida. The overall isolation frequency ( $n=252$ single-spot) of the Neoscytalidium fungus $(29.8 \%)$ is significantly higher than Alternaria $(11.5 \%, P=5 \mathrm{e}-03)$ and Colletotrichum $(0.8 \%, P=5 e-05)$ fungi based on Tukey's honest significance difference test.
Alternaria, Cladosporium, and Colletotrichum) were associated with lesions on pitahaya cladodes. Two weeks after cladodes were inoculated, the Neoscytalidium fungus caused chlorotic spots that progressed and enlarged into brown and macerated lesions, whereas the Alternaria and Colletotrichum fungi incited localized spots on cladodes (Table 1; Supplementary Fig. S1). Although the Cladosporium fungus was also associated with diseased tissue, it was excluded from further investigation because, when inoculated, it only grew epiphytically on cladodes. All negative controls remained healthy after the experiments.

The temporal isolation frequencies for genera Neoscytalidium, Alternaria, and Colletotrichum were between 13.9 and 47.2, 0 and 22.2 , and 0 and $2.8 \%$, respectively (Fig. 1). Among the three genera, the Colletotrichum fungus was detected only from late March to early April, whereas Neoscytalidium and Alternaria fungi were found almost throughout the survey. Based on the ANOVA results, the overall isolation frequency of the Neoscytalidium fungus (29.8\%) was significantly $(P<0.001)$ higher than the other two fungi (Fig. 1; Table 2), suggesting that the Neoscytalidium fungus was the predominant pathogen on pitahaya cladodes during the early fruit production period in South Florida.

To validate the morphology-based identification of the major pathogen on pitahaya, four Neoscytalidium isolates, recovered from the surveyed orchards and used in the pathogenicity tests, were subjected

Table 2. Analysis of variance of the overall isolation frequency of three fungal pathogens on pitahaya cladodes collected in Homestead, Florida, between 19 March and 12 June 2019

\begin{tabular}{lccccc}
\hline Source & $\begin{array}{c}\text { Degrees of } \\
\text { freedom }\end{array}$ & $\begin{array}{c}\text { Sum of } \\
\text { squares }\end{array}$ & $\begin{array}{c}\text { Mean } \\
\text { square }\end{array}$ & $\begin{array}{c}\boldsymbol{F} \\
\text { value }\end{array}$ & $\boldsymbol{P}$ value \\
\hline Fungal genus & 2 & 0.3001 & 0.1501 & 17.03 & $7.06 \mathrm{e}-05$ \\
Error & 18 & 0.1586 & 0.0088 & & \\
Total & 20 & 0.4587 & & & \\
\hline
\end{tabular}

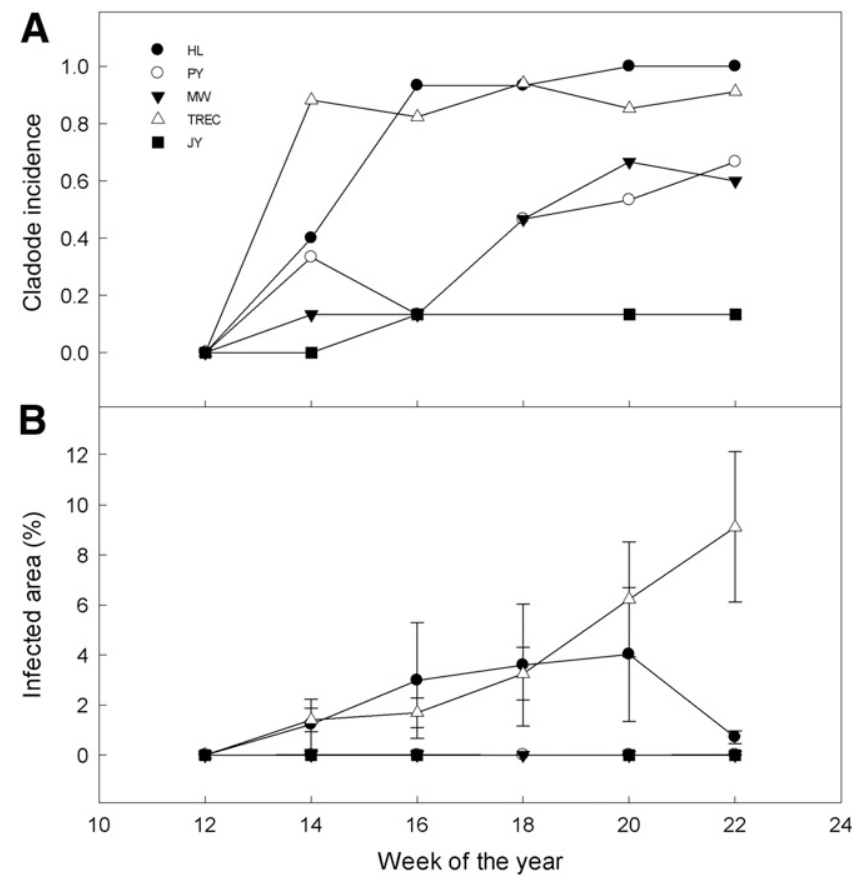

Fig. 2. Temporal dynamics of $\mathbf{A}$, stem canker disease incidence and $\mathbf{B}$, stem canker severity on pitahaya cladodes. Each symbol represents an orchard in Homestead, Florida. Fifteen cladodes were randomly tagged and monitored in each commercial orchard and 34 cladodes were monitored at the Tropical Research and Education Center (TREC) between 19 March and 29 May 2019. Error bars are the standard error of mean. 
to multilocus sequencing. Based on the ITS, $\beta$-tubulin, and EF1- $\alpha$ sequences, all isolates were identified as $N$. dimidiatum (syn. $N$. hyalinum), with $99 \%$ identity for the ITS region (549 bp, accessions KF531816 and KF531820), 99\% identity for $\beta$-tubulin (428 bp, accessions KF531796 and KF531800), and 99.7\% identity for the EF1- $\alpha$ region (282 bp, accessions KF531795 and KF531798). Sequences of the three DNA fragments were deposited in NCBI GenBank with the accession numbers MN520607 to MN520610 for ITS, MN560817 to MN560820 for $\beta$-tubulin, and MN560813 to MN560816 for EF1- $\alpha$.

Temporal dynamics of stem canker and its relationship with fruit canker incidence. Disease progress, as well as canker incidence and severity on cladodes, varied among the surveyed orchards. In general, stem canker intensity increased over time, with the exception of one orchard (HL) where disease severity decreased during weeks 20 to 22 as a result of the removal of diseased cladodes (Fig. 2). Despite the increasing disease incidence in three commercial orchards (PY, MW, and JY), disease severity was relatively low by the end of May. On the other hand, a commercial orchard (HL) and the experimental orchard at TREC had relatively higher canker incidence and severity on cladodes than other orchards. A similar pattern was observed for the sAUDIC and sAUDSC in each orchard (Supplementary Table S2).

A significantly positive relationship between fruit canker incidence and either sAUDIC $(r=0.8788, P=0.0498)$ or sAUDSC ( $r=0.9904, P=0.0011$ ) of stem canker was estimated (Fig. 3 ), suggesting that early-season stem canker intensity was positively associated with fruit canker incidence. Based on Pearson's correlation coefficient and the $P$ value, sAUDSC of stem canker seemed to be a better indicator
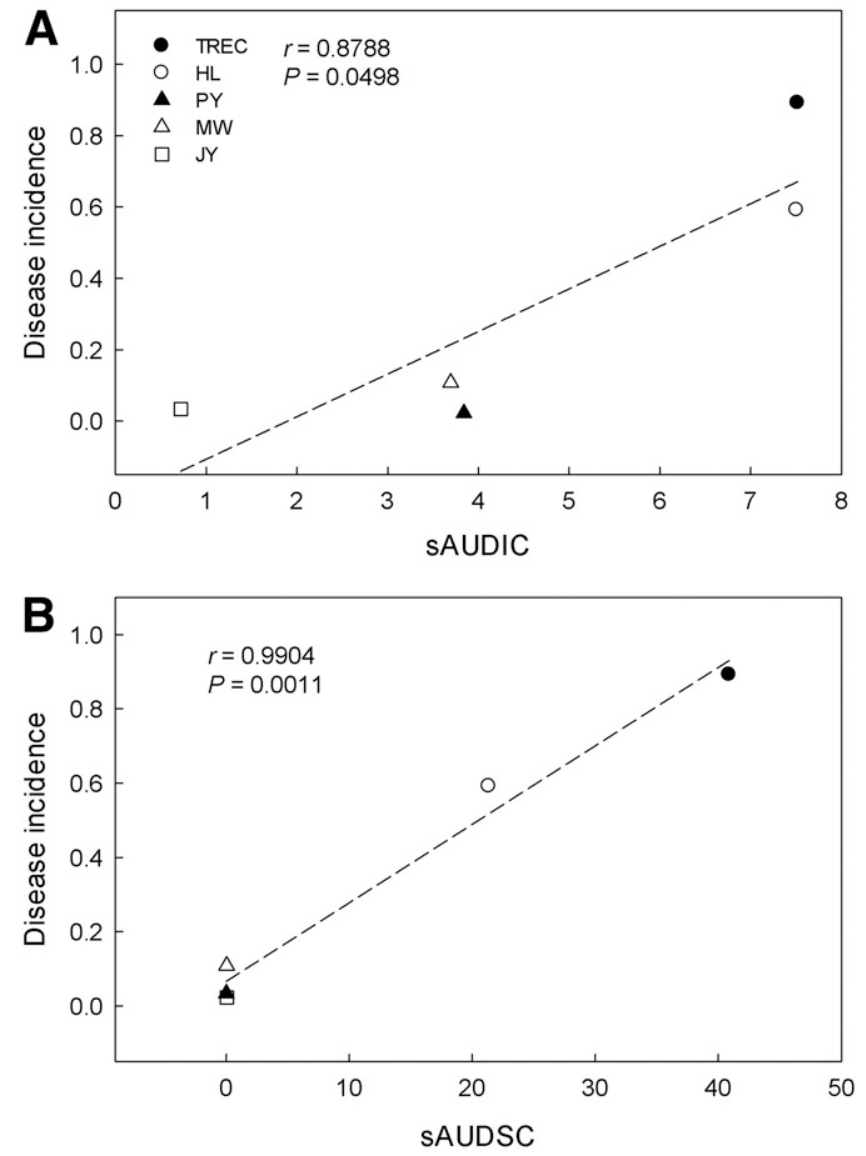

Fig. 3. Relationship between cumulative stem canker intensity and fruit canker incidence. The overall fruit canker incidence is positively correlated with the $\mathbf{A}$, standardized area under the disease incidence curve (SAUDIC) and the B, standardized area under the disease severity curve (SAUDSC) on cladodes between 19 March and 29 May 2019. Each point represents a pitahaya orchard and the dashed line indicates the regression line. TREC $=$ Tropical Research and Education Center and $r=$ Pearson's correlation coefficient. than sAUDIC for predicting fruit canker incidence during production season in South Florida.

Effect of cumulative temperature on conidial germination of $N$. dimidiatum. More conidia germinated during the period when the cumulative temperature was increasing (Fig. 4). However, fewer conidia germinated when the temperature was constantly low (e.g., $15 \pm 1^{\circ} \mathrm{C}$ ); therefore, the proportion of germinated conidia was lower even though a certain cumulative temperature (e.g., $360^{\circ} \mathrm{C}-\mathrm{h}$ ) had been reached. This is reflected by the data points of the germination proportion at $15 \pm 1{ }^{\circ} \mathrm{C}$ clustering at the lower part of the regression plot (Fig. 4, dashed circle).

Based on the logarithmic model (Fig. 4), the maximum germination proportion and the slopes for cumulative temperature (slopes of 0.4661 and 0.4651 for UFE8N1 and PY320N2, and 0.3603 and 0.3505 for MW403N1 and HL321N1, respectively) split into two groups, suggesting that the tested isolates may have a different maximum germination proportion and/or requirements of cumulative temperature. However, regardless of the isolate and based on the model, $>50 \%$ of conidia were predicted to germinate within $24 \mathrm{~h}$ when the temperature was above $22^{\circ} \mathrm{C}$.

Effect of temperature on mycelia growth of $N$.dimidiatum. The mycelial growth rate of $N$. dimidiatum was significantly affected by temperature $(P<0.001)$ but was not significantly different among isolates $(P=0.526)$ (Table 3; Supplementary Table S3). No significant effect between isolate and temperature was observed $(P=$ $0.835)$. The colony area size and the mycelial growth rate increased when the temperature increased from 15 to $32^{\circ} \mathrm{C}$ but significantly decreased $(P<0.01)$ at $37^{\circ} \mathrm{C}$ (Fig. 5), suggesting that $32^{\circ} \mathrm{C}$ was the optimum temperature for mycelial growth among the temperatures tested.

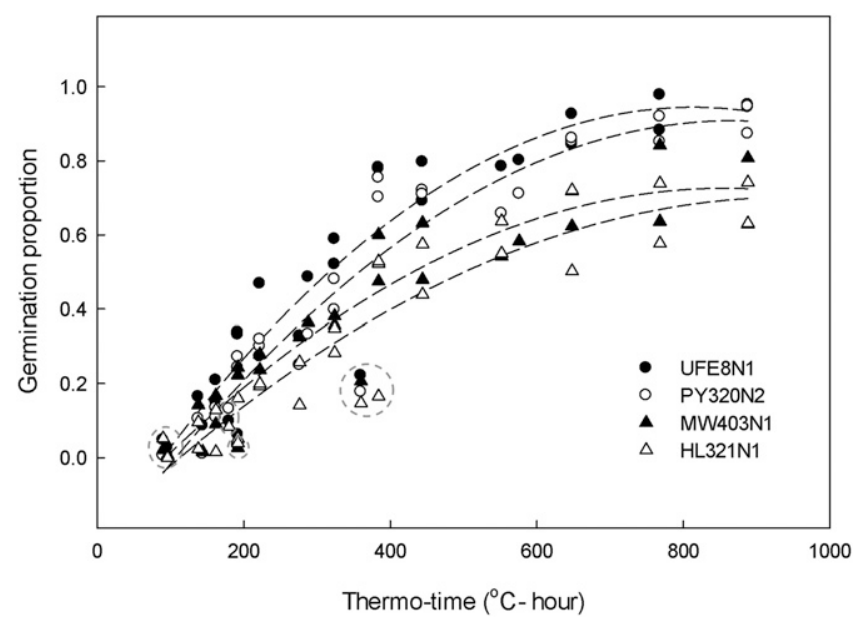

Fig. 4. Effect of cumulative temperature on conidial germination of Neoscytalidium dimidiatum. Each symbol represents an isolate and the dashed lines are the regression lines predicted by the logarithmic model. The logarithmic model for each isolate is as follows: UFE8N1: $y=0.4661 \ln (x)-2.1693, r^{2}=0.8807$; PY320N2: $y=0.4651 \ln (x)-2.2221, r^{2}=0.8876 ; M W 403 N 1: y=0.3603 \ln (x)-1.6943$, $r^{2}=0.8841$; and HL321N1: $y=0.3505 \ln (x)-1.6919, r^{2}=0.831$. Data points within dashed circles represent the germination proportion at $15 \pm 1^{\circ} \mathrm{C}$.

Table 3. Analysis of variance for isolate and temperature effect on the mycelial growth rate of Neoscytalidium dimidiatum

\begin{tabular}{lcrcrc}
\hline Source & $\begin{array}{c}\text { Degrees of } \\
\text { freedom }\end{array}$ & $\begin{array}{c}\text { Sum of } \\
\text { squares }\end{array}$ & $\begin{array}{c}\text { Mean } \\
\text { square }\end{array}$ & $\boldsymbol{F}$ value & $\begin{array}{c}\boldsymbol{P} \\
\text { value }\end{array}$ \\
\hline Isolate & 3 & 0.095 & 0.032 & 0.756 & 0.526 \\
Temperature & 4 & 23.489 & 5.872 & 139.480 & $<2 \mathrm{e}-16$ \\
$\begin{array}{l}\text { Isolate } \times \\
\text { temperature }\end{array}$ & 12 & 0.299 & 0.025 & 0.592 & 0.835 \\
Error & 30 & 1.684 & 0.042 & & \\
\hline
\end{tabular}




\section{Discussion}

Pitahaya production has steadily increased during the past 2 decades in South Florida; however, limited information is available on the major diseases and their epidemiological characteristics. This study focused on the major disease of pitahaya in South Florida and sheds light on its biology, epidemiology, and potential strategies for management.

During the vegetative growth stage, pitahaya cladodes increase in length, stopping elongation before thickening and maturing (C.-F. Hong et al., personal observation; Kishore 2016). Cladodes are susceptible to diseases during the elongation and maturation stage but become more resistant before flower bud emergence (Fullerton et al. 2018; Ni et al. 2013). In this study, the first flower bud was observed in the cultivar Natural Mystic (26 March 2019), but most flower buds in commercial orchards (i.e., in H. undatus 'Vietnamese') emerged around late March to early April. Thereafter, multiple biweekly waves of flower buds emerged, taking approximately 7 to 8 weeks to produce harvestable fruits. Hence, pathogens surviving on or infecting cladodes in the early season may build up disease pressure, thereby affecting flower buds and/or developing fruits during reproductive growth, which is around mid-April to November in South Florida (Crane and Balerdi 2006).

All fungal pathogens isolated from pitahaya cladodes in this study have been previously reported in South Florida (Palmateer et al. 2007; Patel and Zhang 2017; Sanahuja et al. 2016). However, the temporal dynamics of the fungal pathogens had not been documented previously. For instance, the isolation frequencies of genera Alternaria and Colletotrichum were significantly lower than $N$. dimidiatum in the early season, suggesting a potential turnover in the pathogenic species communities. In addition, symptoms caused by genera Alternaria and Colletotrichum were also localized and milder than $N$. dimidiatum. Whether the coexistence of opportunistic or weak pathogens was facilitated by the infection of $N$. dimidiatum should be further investigated. Nevertheless, our results support previous observations by Sanahuja et al. (2016), who reported that canker disease incidence could be as high as $70 \%$ in commercial orchards in South Florida. These reports indicate that $N$. dimidiatum has a major and constant impact on pitahaya production in this region. Similarly, $N$. dimidiatum is considered a major pathogen with significant economic impact on the pitahaya industry in Asia (Ezra et al. 2013; Fullerton et al. 2018; Mohd et al. 2013).

$N$. dimidiatum is considered a necrotrophic pathogen, causing very small, chlorotic, sunken spots on cladodes and immature fruits by secreting toxins during infection (Fullerton et al. 2018). Small chlorotic spots turn into orange to brown spots over time, coalescing to form

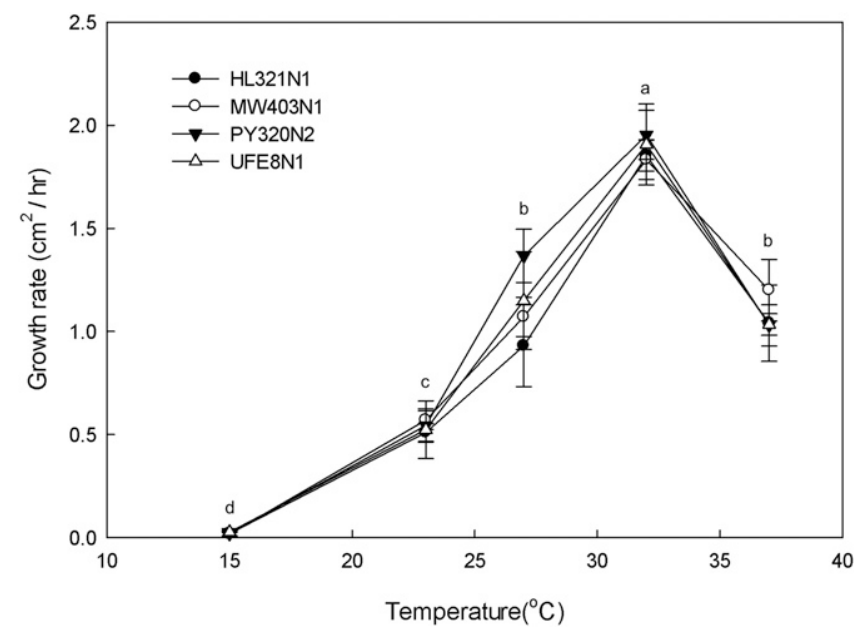

Fig. 5. Effect of temperature on the mycelial growth rate of Neoscytalidium dimidiatum. Different letters indicate the significantly different growth rate among temperatures at a $P=0.001$ confidence level based on Tukey's honest significance difference. Bars are the standard error of mean. round, orange to brown watery lesions, which sometimes are surrounded by a yellow halo. Depending on the weather conditions, infected cladodes may dry out and eventually form "shot-hole" symptoms, with black, concentric pycnidia on dried tissues. The arthroconidia and pycniospores that survive or are formed on diseased cladodes have been hypothesized as the source of secondary inoculum, leading to secondary infections on cladodes and fruits (Ni et al. 2013). During our field survey, pitahaya fruits below or in proximity to the cladodes with stem canker usually had higher severity compared to those without stem canker. In the five surveyed orchards, a positive relationship between early-season stem canker intensity and fruit canker incidence was found. This suggests that spores of $N$. dimidiatum produced on diseased cladodes during the early season may contribute to secondary infections on developing fruits. Although the inocula might have come from other crops such as mango, citrus, guava, and tomato, which are commonly planted in this region and have been reported as hosts of $N$. dimidiatum (Mayorquin et al. 2016; Sakalidis et al. 2011; Türkölmez et al. 2019), there is currently no record of $N$. dimidiatum infecting the aforementioned hosts in Florida (Farr and Rossman 2019). Hence, cladodes with cankers in the early season are likely the main source of inoculum causing fruit canker.

$N$. dimidiatum has been reported to cause internal black rot in pitahaya fruits in Israel and China (Ezra et al. 2013; Yi et al. 2015). Although the symptoms have not been documented in this region, we cannot exclude the possibility of its development in local commercial fields. Even though symptoms caused by $N$. dimidiatum on fruit are mostly superficial, the aesthetic value impacted by the disease could lead to $>60$ to $80 \%$ loss of market value, according to growers in South Florida (M. Tun et al., personal communication). To maintain low inoculum thresholds and therefore minimize disease pressure on fruits, management of stem canker during the early season of pitahaya production is important.

The maximum germination proportion and the slopes for conidial germination of the four tested isolates of $N$. dimidiatum split into two groups: more conidia of $N$. dimidiatum isolates UFE8N1 and PY320N2 germinated than isolates MW403N1 and HL321N1 at the same temperature, suggesting potential phenotypic variations on the requirement of cumulative temperature in the local $N$. dimidiatum populations. In addition, in vitro mycelial growth was significantly faster at $32^{\circ} \mathrm{C}$ than other tested temperatures, suggesting that the pathogen prefers higher temperatures. Similar results were documented in Brazil, California, and Taiwan where more $N$. dimidiatum conidia germinated at $35^{\circ} \mathrm{C}$, but the optimum temperature for mycelial growth was between 25 and $35^{\circ} \mathrm{C}$, although the isolates from Brazil and California were isolated from mango and almond, respectively (Marques et al. 2013; Ni et al. 2013; Nouri et al. 2018).

Based on the logarithmic model of conidial germination, $>50 \%$ of $N$. dimidiatum conidia were predicted to germinate within $24 \mathrm{~h}$, when the temperature was $>22^{\circ} \mathrm{C}$. In South Florida, the number of days with an average temperature above $22^{\circ} \mathrm{C}$ between January and June increased over the past five years (University of Florida 2019) (Supplementary Table S4). Although the threshold of 50\% conidial germination may be difficult to translate to field infection, conidial germination and mycelial growth rates are positively correlated with increasing temperature, along with increasing number of days with higher daily average temperature; these results suggest that management strategies should start early to minimize the risk of conidia germination and subsequent infection. This study has generated baseline knowledge on the epidemiology and biology of the major pathogens of pitahaya commercial production during the early production season in South Florida. Further studies on fungicide efficacy, application timing, and fungicide rotations will be needed to design a science-based integrated pest management program.

\section{Acknowledgments}

We thank the pitahaya growers in Homestead, Florida, who allowed us to conduct the field survey and collect samples from their orchards. We also appreciate Amanda Sandford for assisting with the laboratory work. 


\section{Literature Cited}

Carbone, I., and Kohn, L. M. 1999. A method for designing primer sets for speciation studies in filamentous ascomycetes. Mycologia 91:553-556.

Chang, F.-R., and Yen, C.-R. 1997. Flowering and fruit growth of pitaya (Hylocereus undatus Britt. \& Rose). J. Chin. Soc. Hortic. Sci. 43:314-321.

Crane, J. H. 2018. Tropical fruit production in Florida: Trials, tribulations and opportunities. Pages ix-xii in: Proceedings of the 131st Annual Meeting of the Florida State Horticultural Society. M. Lamberts, ed. Florida State Horticultural Society, Lake Alfred, FL.

Crane, J. H., and Balerdi, C. F. 2006. Pitaya Growing in the Florida Home Landscape. UF/IFAS Ext. HS1068. University of Florida, Gainesville. https:// edis.ifas.ufl.edu/hs303

Crop Data Management Systems. 2019. Crop data management systems. http:// www.cdms.net/

Evans, E., and Huntley, J. 2011. Economics of establishing and producing pitaya in southern Florida: A stochastic budget analysis. HortTechnology 21(2): 246-251.

Ezra, D., Liarzi, O., Gat, T., Hershcovich, M., and Dudai, M. 2013. First report of internal black rot caused by Neoscytalidium dimidiatum on Hylocereus undatus (pitahaya) fruit in Israel. Plant Dis. 97:1513.

Farr, D. F., and Rossman, A. Y. 2019. Fungal Databases. U.S. National Fungus Collections, U.S. Department of Agriculture Agricultural Research Service. https://nt.ars-grin.gov/fungaldatabases/

Fernandez de Soto, J., Lobo, R., Aguiar, J. L., Deborah, M. M., and Tanizaki, G. 2014. Cactus virus $X(\mathrm{CVX})$ a new threat to pitahaya/dragon fruit (Hylocereus spp.) production in California. HortScience 49:S397.

Fullerton, R. A., Sutherland, P. A., Rebstock, R. S., Nguyen, T. H., Nguyen, N. A. T., Dang, T. L., Ngo, T. K. T., and Nguyen, V. H. 2018. The life cycle of dragon fruit canker caused by Neoscytalidium dimidiatum and implications for control. Pages 71-80 in: Proceedings of the Dragon Fruit Regional Network Initiation Workshop. Food and Fertilizer Technology Center, Taipei, Taiwan.

Gazis, R., Poudel, B., Dey, K. K., Zhang, S., Palmateer, A. J., Campoverde, E. V., Baker, C. A., and Adkins, S. 2018. First report of Cactus virus $X$ in Hylocereus undatus (dragon fruit) in Florida. Plant Dis. 102:2666.

Glass, N. L., and Donaldson, G. C. 1995. Development of primer sets designed for use with the PCR to amplify conserved genes from filamentous ascomycetes. Appl. Environ. Microbiol. 61:1323-1330.

Jiang, Y. L., Liao, Y. Y., Lin, T. S., Lee, C. L., Yen, C. R., and Yang, W. J. 2012. The photoperiod-regulated bud formation of red pitaya (Hylocereus sp.). HortScience 47:1063-1067.

Kearse, M., Moir, R., Wilson, A., Stones-Havas, S., Cheung, M., Sturrock, S., Buxton, S., Cooper, A., Markowitz, S., Duran, C., Thierer, T., Ashton, B., Meintjes, P., and Drummond, A. 2012. Geneious basic: An integrated and extendable desktop software platform for the organization and analysis of sequence data. Bioinformatics 28:1647-1649.

Kishore, K. 2016. Phenological growth stages of dragon fruit (Hylocereus undatus) according to the extended BBCH-scale. Sci. Hortic. (Amsterdam) 213:294-302.

Marques, M. W., Lima, N. B., de Morais, M. A., Jr., Michereff, S. J., Phillips, A. J. L., and Câmara, M. P. S. 2013. Botryosphaeria, Neofusicoccum, Neoscytalidium and Pseudofusicoccum species associated with mango in Brazil. Fungal Divers. 61:195-208.

Mayorquin, J. S., Wang, D. H., Twizeyimana, M., and Eskalen, A. 2016. Identification, distribution, and pathogenicity of Diatrypaceae and Botryosphaeriaceae associated with citrus branch canker in the Southern California desert. Plant Dis. 100:2402-2413.

Merten, S. 2003. A review of Hylocereus production in the United States. J. PACD. 5:98-105.

Mizrahi, Y., Nerd, A., and Nobel, P. S. 1997. Cacti as crops. Pages 291-320 in: Horticultural Reviews. J. Janick, ed. John Wiley \& Sons, Inc., New York, NY.

Mohd, M. H., Salleh, B., and Zakaria, L. 2013. Identification and molecular characterization of Neoscytalidium dimidiatum causing stem canker of redfleshed dragon fruit (Hylocereus polyrhizus) in Malaysia. J. Phytopathol. 161:841-849.

Ni, H.-F., Huang, C.-W., Hsu, S.-L., Lai, S.-Y., and Yang, H.-R. 2013. Pathogen characterization and fungicide screening of stem canker of pitaya. J. Taiwan Agricul. Res. 62:225-234.
Nouri, M. T., Lawrence, D. P., Yaghmour, M. A., Michailides, T. J., and Trouillas, F. P. 2018. Neoscytalidium dimidiatum causing canker, shoot blight and fruit rot of almond in California. Plant Dis. 102:1638-1647.

Ortíz-Hernández, Y. D., and Carrillo-Salazar, J. A. 2012. Pitahaya (Hylocereus spp.): A short review. Comun. Sci. 3:220-237.

Osuna-Enciso, T., Valdez-Torres, J. B., Sañudo-Barajas, J. A., Muy-Rangel, M. D., Hernández-Verdugo, S., Villarreal-Romero, M., and OsunaRodríguez, J. M. 2016. Reproductive phenology, yield and fruit quality of pitahaya (Hylocereus undatus (How.) Britton and Rose) in Culiacan Valley, Sinaloa, Mexico. Agrociencia 50:61-78.

Pagliaccia, D., Vidalakis, G., Douhan, G. W., Lobo, R., and Tanizaki, G. 2015. Genetic characterization of pitahaya accessions based on amplified fragment length polymorphism analysis. HortScience 50:332-336.

Palmateer, A. J., Ploetz, R. C., Van Santen, E., and Correll, C. 2007. First occurrence of anthracnose caused by Colletotrichum gloeosporioides on pitahaya. Plant Dis. 91:631.

Patel, J. S., and Zhang, S. 2017. First report of Alternaria blight of pitahaya (Hylocereus undatus) caused by Alternaria sp. in South Florida of the United States. Plant Dis. 101:1046.

R Core Team. 2018. R: A Language and Environment for Statistical Computing. R Foundation for Statistical Computing, Vienna, Austria. https://www.r-project.org/

Raveh, E., Weiss, J., Nerd, A., and Mizrahi, Y. 1993. Pitayas (genus Hylocereus): A new fruit crop for the Negev desert of Israel. Pages 491-495 in: New Crops. Janick, J., and Simson, J. E., eds. Wiley, New York, NY.

Sakalidis, M. L., Ray, J. D., Lanoiselet, V., Hardy, G. E. S., and Burgess, T. I. 2011. Pathogenic Botryosphaeriaceae associated with Mangifera indica in the Kimberley region of western Australia. Eur. J. Plant Pathol. 130:379-391.

Sanahuja, G., Lopez, P., and Palmateer, A. J. 2016. First report of Neoscytalidium dimidiatum causing stem and fruit canker of Hylocereus undatus in Florida. Plant Dis. 100:1499.

Schindelin, J., Arganda-Carreras, I., Frise, E., Kaynig, V., Longair, M., Pietzsch, T., Preibisch, S., Rueden, C., Saalfeld, S., Schmid, B., Tinevez, J.-Y., White, D. J., Hartenstein, V., Eliceiri, K., Tomancak, P., and Cardona, A. 2012. Fiji: An opensource platform for biological-image analysis. Nat. Methods 9:676-682.

Schneider, C. A., Rasband, W. S., and Eliceiri, K. W. 2012. NIH Image to ImageJ: 25 years of image analysis. Nat. Methods 9:671-675.

Shaner, G., and Finney, R. E. 1977. The effect of nitrogen fertilization in the expression of slow-mildewing resistance in Knox wheat. Phytopathology 67: 1051-1056.

Steele, D., and Crane, J. H. 2006. The state of the Florida tropical fruit industry and the challenges growers face. Proc. Fla. State Horticul. Soc. 119:7-8.

Taba, S., Miyahira, N., Nasu, K., Takushi, T., and Moromizato, Z. 2007. Fruit rot of strawberry pear (pitaya) caused by Bipolaris cactivora. J. Gen. Plant Pathol. 73:374-376.

Takahashi, L. M., Rosa, D. D., Basseto, M. A., de Souza, H. G., and Furtado, E. L. 2008. First report of Colletotrichum gloeosporioides on Hylocereus megalanthus in Brazil. Australas. Plant Dis. Notes 3:96-97.

Tarnowski, T. L. B., Palmateer, A. J., and Crane, J. H. 2010. First report of fruit rot on Hylocereus undatus caused by Bipolaris cactivora in South Florida. Plant Dis. 94:1506.

Türkölmez, Ş., Derviş, S., Çiftçi, O., Serçe, Ç. U., and Dikilitas, M. 2019. New disease caused by Neoscytalidium dimidiatum devastates tomatoes (Solanum lycopersicum) in Turkey. Crop Prot. 118:21-30.

University of Florida. 2019. Florida Automated Weather Network (FAWN) report generator. University of Florida Institute of Food and Agricultural Sciences, Gainesville. https://fawn.ifas.ufl.edu/data/reports/

Wang, C. L., and Lin, C. C. 2005. Fruit rot of pitaya and stem rot of cacti in Taiwan. Plant Pathol. Bull. 14:269-274.

Weiss, J., Nerd, A., and Mizrahi, Y. 1994. Flowering behavior and pollination requirements in climbing cacti with fruit crop potential. HortScience 29: 1487-1492.

White, T. J., Bruns, T., Lee, S., and Taylor, J. W. 1990. Amplification and direct sequencing of fungal ribosomal RNA genes for phylogenetics. Pages 315-322 in: PCR Protocols: A Guide to Methods and Applications. M. A. Innis, D. H. Gelfand, J. J. Sninsky, and T. J. White, eds. Academic Press, San Diego, CA.

Yi, R. H., Lin, Q. L., Mo, J. J., Wu, F. F., and Chen, J. 2015. Fruit internal brown rot caused by Neoscytalidium dimidiatum on pitahaya in Guangdong Province, China. Australas. Plant Dis. Notes 10:13. 